\title{
PROFITABILITAS, UKURAN PERUSAHAAN, DAN NILAI PERUSAHAAN TERHADAP PRAKTIK PERATAAN LABA
}

\author{
Hermawati Nurciptaning Arum \\ hermawatiarum1912@gmail.com \\ Mohamad Rafki Nazar \\ Wiwin Aminah \\ Fakultas Ekonomi dan Bisnis, Universitas Telkom
}

\begin{abstract}
Income smoothing is strategy where management increases or decreases profits to reduce fluctuation. Income smoothing is common form of profit management. Income smoothing measured using Eckel Index which can distinguish between companies that did and did not undertake income smoothing. Eckel uses CV for profit and net income. Index which has a result less than 1 is classified as a grader, index which has a result more than 1 is classified as nongrader. This study aims to determine the effect of profitability, firm size, and value of company on income smoothing. The object using company registered in Jakarta Islamic Index 2011-2015. Sampling technique used in this study is purposive sampling. Analytical method used in this study is logistic regression. The results show that profitability, company size, and value of company simultaneously influence income smoothing. Partially, profitability and company size significantly negative direction of income smoothing, the value of the company have significant influence with a positive direction toward the practice of income smoothing.
\end{abstract}

Keywords : profitability, firm size, value of firm, income smoothing

\begin{abstract}
Abstrak
Perataan laba adalah sebuah strategi manajemen meningkatkan atau menurunkan laba untuk mengurangi fluktuasinya Perataan laba adalah bentuk umum dari manajemen laba. Perataan laba diukur dengan Indeks Eckel yang dapat membedakan antara perusahaan melakukan perataan laba dan tidak melakukan. Eckel menggunakan CV untuk laba dan pendapatan bersih. Indeks yang memiliki hasil $<1$ maka digolongkan sebagai perata, sedangkan indeks yang memiliki hasil $>1$ digolongkan sebagai bukan perata. Penelitian ini bertujuan untuk mengetahui pengaruh profitabilitas, ukuran perusahaan, dan nilai perusahaan terhadap perataan laba, penelitian ini menggunakan perusahaan yang terdaftar dalam Jakarta Islamic Index tahun 2011-2015 dengan sampel menggunakan teknik purposive sampling dan menggunakan metode analisis regresi logistic. Hasil penelitian menunjukkan bahwa secara simultan variabel profitabilitas, ukuran perusahaan, dan nilai perusahaan berpengaruh terhadap praktik perataan laba. Secara parsial profitabilitas dan ukuran perusahaan berpengaruh negatif terhadap praktik perataan laba, sedangkan nilai perusahaan berpengaruh positif terhadap praktik perataan laba.
\end{abstract}

Kata Kunci : profitabilitas, ukuran perusahaan, nilai perusahaan, perataan laba 


\section{PENDAHULUAN}

Laporan keuangan merupakan catatan ringkas yang berisi informasi keuangan suatu perusahaan pada periode tertentu yang merupakan bentuk pertanggungjawaban manajemen atas sumber daya yang diberikan oleh pemilik (Putri dan Yuyetta, 2013). Laporan keuangan juga merupakan cerminan dari suatu kondisi perusahaan, karena di dalam laporan keuangan terdapat informasi-informasi yang dibutuhkan oleh pihak-pihak yang berkepentingan dengan perusahaan. Pemakai laporan keuangan dapat dibedakan menjadi beberapa pihak, yaitu: manajemen, pemegang saham, kreditor, pemerintah, karyawan perusahaan, pemasok, konsumen, dan masyarakat umum lainnya yang pada dasarnya dapat dibedakan menjadi 2 kelompok besar yaitu pihak eksternal dan pihak internal (Hery, 2015).

Salah satu parameter yang digunanakan untuk mengukur kinerja manajemen adalah laba. Laba beserta komponennya yang terdapat dalam pelaporan keuangan dapat menunjukkan informasi suatu entitas bisnis mengenai prestasi yang diraihnya. Laba yang dilaporkan merupakan informasi yang berharga bagi pihak internal dan eksternal. Informasi laba dalam laporan keuangan bertujuan untuk menaksir risiko investasi atau meminjamkan dana, membantu mengestimasi kemampuan laba, dan menilai kinerja manajemen (Marpaung dan Latrini, 2014). Hal ini sesuai dengan Pernyataan Standar Akuntansi (IAI, 2015) yang menyatakan bahwa informasi kinerja perusahaan, terutama profitabilitas, diperlukan untuk menilai perubahan potensial sumber daya ekonomi yang mungkin dikendalikan di masa depan.

Informasi yang terkandung dalam laba bertujuan untuk mengetahui bagaimana kinerja dari manajemen apakah baik atau tidak, membantu memprediksi hasil laba di masa datang, dan memprediksi kemampuan perusahaan meminjam dana kepada investor. Perhatian investor seringkali terpusat pada laba sehingga hal tersebut membuat manajemen terdorong untuk melakukan perilaku yang tidak semestinya (dysfunctional behavior). Pada umumnya, perhatian para pemakai laporan keuangan hanya berfokus pada laba yang terdapat dalam laporan laba rugi untuk menilai kinerja sebuah perusahaan yang digunakan untuk mengambil keputusan, oleh karena itu, manajemen menyadari hal ini dan cenderung melakukan manajemen laba. (Peranasari dan Dharmadiaksa, 2014).

Subramanyam dan Wild (2013) menyebutkan bahwa terdapat tiga jenis manajemen laba. (1) Manajer meningkatkan laba (increasing income) periode kini. (2) Manajer melakukan "mandi besar" (big bath) melalui pengurangan laba periode in. (3) Manajer mengurangi fluktuasi laba dengan perataan laba (income smoothing). Seringkali manajer melakukan satu atau kombinasi dari ketiga strategi ini pada waktu yang berbeda untuk mencapai tujuan manajemen laba jangka panjang. Manajemen laba merupakan perilaku yang tidak semestinya dari manajemen. Bentuk dari manajemen laba yang kerap dilakukan oleh manajer adalah perataan laba.

Perataan laba adalah pengurangan fluktuasi laba dari tahun ke tahun dengan memindahkan pendapatan dari tahun-tahun yang tinggi pendapatannya ke periode yang kurang menguntungkan (Riahi dan Belkaoui, 2007). Perataan laba juga merupakan bentuk rekayasa pendapatan yang dirancang untuk menghilangkan fluktuasi sederetan pendapatan (Mulford dan Comiskey, 2010). Wulandari, Arfan, dan Shabri (2013) menyatakan bahwa perataan laba dilakukan terutama untuk menunjukkan kinerja perusahaan dan keadaan keuangan. Tujuan yang melatarbelakangi manajemen melakukan perataan laba tetap saja dapat mengubah kandungan informasi atas laba yang dihasilkan perusahaan. Hal ini perlu diwaspadai oleh pengguna laporan keuangan karena informasi yang telah mengalami penambahan atau pengurangan tersebut dapat menyesatkan pengambilan keputusan.

Terdapat beberapa alasan yang membuat manajemen melakukan perataan laba yaitu untuk memenuhi target internal, memenuhi harapan pihak eksternal, membuat laba stabil, dan agar laporan keungan seolah-olah nampak baik demi kepentingan perusahaan (Hery, 2015). Perataan laba dianggap sebagai kecurangan karena manajemen melakukan perubahan terhadap akun dalam laporan keuangan yang dilakukan secara sadar, dimana informasi yang dihasilkan dapat mengelabuhi investor dan pemegang saham mengenai kondisi finansial perusahaan yang sebenarnya. Yayasan Pendidikan Internal Audit dalam buku yang berjudul Fraud Auditing (2008) menyatakan bahwa kecurangan yang dilakukan oleh manajemen biasanya dilakukan dengan menyajikan laporan keuangan yang tidak benar untuk keuntungan organisasi atau untuk perusahaan. Untuk menarik investor, manajemen merkayasa laporan keuangannya yang tidak baik menjadi seolah-olah menguntungkan. Yang menjadi korban akibat perilaku tersebut adalah publik investor. Hal tersebut dapat merugikan stakeholder perusahaan. Kecurangan ini termasuk dalam kategori kejahatan kerah putih.

Perataan laba yang belum lama terjadi yaitu kasus manipulasi laba Toshiba. Tim penyelidik independen menemukan bahwa direktur utama Toshiba mengetahui bahwa perusahaan memanipulasi laporan keuntungan dengan nilai US\$1,2 miliar selama beberapa tahun. Laporan oleh akuntan independen dengan pengacara menyatakan bahwa laba operasional Toshiba telah dibesar-besarkan sebesar US\$1,22 miliar dari tahun 2008 hingga 2015. Menurut penyelidikan yang dilakukan, hal tersebut terjadi karena adanya tekanan divisi bisnis untuk memenuhi target laba yang sulit, toshiba melebih-lebihkan laba dan menunda laporan kerugian. (www.bisnis.liputan6.com)

Kasus mengenai perataan laba lainnya juga 
dilakukan oleh PT Ancora Resource (OKAS). Ancora Mining Services dilaporkan Forum Masyarakat Peduli Keadilan (FMPK) atas tudingan dugaan penyelewengan pajak. Dugaan manipulasi tersebut dilakukan pada neraca, laporan laba rugi, serta laporan perubahan modal yang berakhir pada 31 Desember 2008. (www. okezone.com).

Selain praktik perataan laba yang dilakukan oleh Toshiba dan PT. Ancora Reasources Tbk (OKAS), praktik perataan laba juga dilakukan oleh PT. Timah (Persero) Tbk (TINS). Ikatan Karyawan Timah (IKT) menilai direksi telah banyak melakukan kebohongan publik melalui media. Contohnya adalah pada saat press release laporan keuangan semester I-2015 yang mengatakan bahwa efisiensi dan strategi yang ada telah membuahkan kinerja yang positif. Padahal kenyataanya pada semester I-2015 laba operasi rugi sebesar Rp59 miliar (www.okezone.com).

Biasanya perataan laba terjadi karena adanya asimetri informasi antara manajemen dan pemilik perusahaan. Manajemen terdorong untuk melakukan perataan laba karena manajemen berupaya untuk meningkatkan penjualan saham, menurunkan tingkat pajak, dan mendapatkan bonus. Perataan laba telah banyak digunakan sebagai topik penelitian-penelitian sebelumnya. Terdapat beberapa ukuran yang dipakai untuk mendeteksi faktor-faktor yang mendorong manajemen melakukan praktik perataan laba berdasarkan penelitian sebelumnya, antara lain profitabilitas, leverage, ukuran perusahaan, risiko keuangan, net profit margin, total debt to total asset, debt to equity ratio, good corporate governance, konservatisme akuntansi, dewan komisaris independen, komite audit, kualitas audit, nilai perusahaan, kepemilikan manajemen, dan agency cost. Pada penelitian ini variabel independen yang digunakan adalah profitabilitas, ukuran perusahaan, dan nilai perusahaan. Dasar pemilihan variabel-variabel tersebut karena pada penelitian-penelitian terdahulu masih banyak terdapat inkonsistensi yang ada dari hasil penelitian yang dilakukan sebelumnya. Oleh karena itu penulis memilih variabel profitabilitas, ukuran perusahaan, dan nilai perusahaan untuk memperkuat hasil penelitian mengenai perataan laba yang telah dilakukan sebelumnya.

Alasan dipilihnya Jakarta Islamic Index sebagai objek penelitian adalah karena perataan laba dianggap sebagai hal yang negatif karena informasi yang disajikan oleh manajemen perusahaan tidak menunjukkan informasi yang sesungguhnya. Hal tersebut merupakan perilaku yang tidak semestinya dilakukan oleh manajemen. Oleh karena itu penulis ingin mengetahui apakah masih terdapat perusahaan yang melakukan praktik perataan laba dalam perusahaan yang terdaftar di Jakarta Islamic Index dimana saham-sahamnya telah memenuhi kriteria syariah Islam. Tujuan dari penelitian ini yaitu untuk mengetahui pengaruh profitabilitas, ukuran perusahaan dan nilai perusahaan terhadap praktik perataan laba secara simultan dan parsial pada perusahaan yang terdaftar di Jakarta Islamic Index tahun 2011-2015.

Profitabilitas merupakan kemampuan perusahaan dalam menghasilkan laba. Perusahaan yang memiliki tingkat profitabilitas yang tinggi mencerminkan kemampuan manajemen dalam mengelola perusahaan untuk menghasilkan laba. Semakin tinggi profitabilitas maka semakin baik, artinya perusahaan memiliki kinerja yang baik dalam menghasilkan laba bersih baik dari hasil penjualan maupun modal sendiri (Widana dan Yasa, 2013).

Penelitian ini menggunakan return on asset (ROA) sebagai rasio pengukurannya. ROA diukur dengan cara perbandingan antara laba bersih dengan total aset. ROA menunjukkan kemampuan dari modal yang diinvestasikan kedalam bentuk total aktiva untuk menghasilkan laba.

Semakin tinggi nilai profitabilitas maka perusahaan akan cenderung melakukan perataan laba karena perusahaan yang memiliki profitabilitas tinggi mencerminkan kinerja perusahaan yang baik sehingga investor tertarik untuk menanamkan modalnya pada perusahaan tersebut. Penelitian Peranasari dan Dharmadiaksa (2014), menyatakan bahwa profitabilitas berpengaruh positif terhadap praktik perataan laba dan penelitian yang dilakukan oleh Dewi dan Sujana (2014), juga menyatakan bahwa profitabilitas berpengaruh terhadap praktik perataan laba. Hipotesis yang diajukan, profitabilitas berpengaruh positif terhadap praktik perataan laba.

Ukuran perusahaan merupakan salah satu faktor yang mempengaruhi perataan laba. Perusahaan yang memiliki ukuran lebih besar cenderung memiliki dorongan yang lebih besar untuk melakukan perataan laba karena perusahaan yang berukuran besar biasanya menjadi subjek pengawasan yang lebih ketat dari pemerintah maupun masyarakat umum. Perusahaan besar diperkirakan menghindari fluktuasi laba yang drastis karena akan menyebabkan pajak perusahaan meningkat begitu pula sebaliknya (Supriastuti, 2015).

Penelitian Peranasari dan Dharmadiaksa (2014), menyatakan bahwa ukuran perusahaan berpengaruh positif terhadap praktik perataan laba dan penelitian yang dilakukan oleh Widana dan Yasa (2013), juga menyatakan bahwa ukuran perusahaan berpengaruh signifikan terhadap praktik perataan laba. Hipotesis yang diajukan, ukuran perusahaan berpengaruh positif terhadap perataan laba.

Nilai perusahaan yang baik membentuk citra perusahaan yang baik bagi investor sehingga investor cenderung membeli saham pada perusahaan dengan nilai pasar yang baik (Peranasari dan Dharmadiaksa, 2014). Perusahaan yang memiliki nilai perusahaan yang tinggi akan cenderung melakukan praktik perataan laba. Hal ini dikarenakan suatu perusahaan dengan nilai yang tinggi memiliki tingkat kestabilan laba yang tinggi pula sehingga dapat lebih menarik investor untuk 
menanamkan modal pada perusahaan tersebut.

Penelitian Peranasari dan Dharmadiaksa (2014), menyatakan bahwa nilai perusahaan berpengaruh positif terhadap praktik perataan laba dan penelitian yang dilakukan oleh Cahyani (2012), juga menyatakan bahwa ukuran perusahaan berpengaruh terhadap praktik perataan laba. Hipotesis yang diajukan, nilai perusahaan berpengaruh positif terhadap praktik perataan laba.

\section{METODE}

Populasi yang digunakan sebagai bahan penelitian adalah perusahaan yang terdaftar di Jakarta Islamic Index tahun 2011-2015. Teknik sampel yang digunakan dalam penelitian ini adalah purposive sampling. Kriteria-kriteria pemilihan sampel dalam penelitian ini adalah sebagai berikut:

Tabel 1. Kriteria Pengambilan Sampel

\begin{tabular}{|c|c|c|}
\hline No & Kriteria Sampel & Jumlah \\
\hline 1. & $\begin{array}{l}\text { Perusahaan yang terdaftar dalam Jakarta Islamic } \\
\text { Index tahun } 2011-2015\end{array}$ & 30 \\
\hline 2. & $\begin{array}{l}\text { Perusahaan yang terdaftar secara tidak konsisten di } \\
\text { Jakarta Islamic Index selama periode pengamatan } \\
2011-2015\end{array}$ & (19) \\
\hline 3. & $\begin{array}{l}\text { Perusahaan di JII yang tidak mempublikasikan } \\
\text { laporan keuangan tahunan yang sudah di audit } \\
\text { selama periode pengematan } 2011-2015 \text { di } \\
\text { website BEI. }\end{array}$ & 0 \\
\hline \multicolumn{2}{|c|}{ Total } & 11 \\
\hline \multicolumn{2}{|c|}{ Jumlah pengamatan selama 5 tahun } & 55 \\
\hline
\end{tabular}

Berdasarkan Tabel 1 dihasilkan sampel penelitian sebanyak 11 perusahaan dan jumlah pengamatan selama 5 tahun sehingga didapatkan 55 jumlah data. Teknik analisis yang digunakan dalam penelitian ini menggunakan analisis statistik deskriptif dan regresi logistik. Operasionalisasi variabel ditunjukkan pada Tabel 2.

\section{HASIL}

Tabel 3. Distribusi Sampel Berdasarkan Perataan Laba

\begin{tabular}{lccccccc}
\hline Kategori & $\mathbf{2 0 1 1}$ & $\mathbf{2 0 1 2}$ & $\mathbf{2 0 1 3}$ & $\mathbf{2 0 1 4}$ & $\mathbf{2 0 1 5}$ & Total & Presentase \\
\hline $\begin{array}{l}\text { Smoother } \\
\begin{array}{l}\text { Non- } \\
\text { smoother }\end{array}\end{array}$ & 5 & 7 & 4 & 3 & 8 & 28 & $50,91 \%$ \\
\hline \multicolumn{1}{c}{ Total } & 11 & 11 & 11 & 11 & 11 & 55 & $100 \%$ \\
\hline Sumber: Data sekunder yang diolah & & &
\end{tabular}

Dapat dilihat bahwa dari total sampel penelitian yang berjumlah 55 sampel penelitian menunjukkan bahwa sebanyak 28 sampel atau 50,91\% perusahaan melakukan perataan laba. Sementara itu sisanya sebanyak 27 sampel penelitian atau 49,09\% tidak melakukan perataan laba. Hal ini menunjukkan bahwa di dalam Jakarta Islamic Index masih terdapat perusahaan yang melakukan praktik perataan laba untuk menciptakan laporan keuangan yang terkesan stabil labanya di mata investor.

Tabel 4. Statistik Deskriptif Variabel Independen

\begin{tabular}{lccc}
\hline & ROA & LN PENJUALAN & PBV \\
\hline $\mathbf{N}$ & 55 & 55 & 55 \\
Minimum & 2,48 & 7,23 & 0,88 \\
Maximum & 41,50 & 12,21 & 82,13 \\
Mean & 15,37 & 9,88 & 9,07 \\
Std. Deviation & 9,49 & 1,23 & 20,23 \\
\hline
\end{tabular}

Sumber: Data sekunder yang diolah

Dari data tersebut tersebut dapat dilihat bahwa, variabel profitabilitas yang diproksikan dengan ROA dan variabel ukuran perusahaan yang diproksikan dengan logaritma natural total penjualan memiliki nilai mean yang lebih besar dari standar deviasi yang dapat diartikan bahwa data variabel tersebut berkelompok atau tidak bervariasi. Sedangkan, variabel nilai perusahaan yang diproksikan dengan price to book value

Tabel 2. Tabel Operasionalisasi Variabel

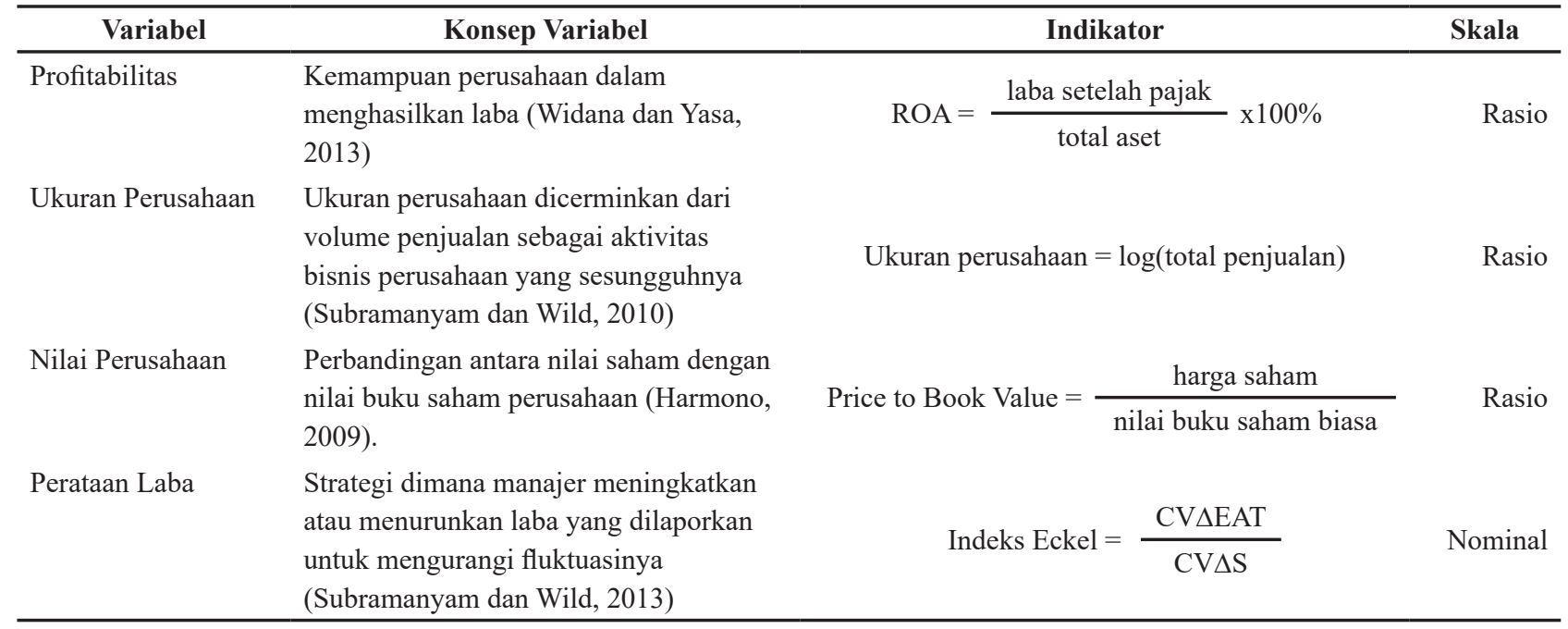


memiliki mean yang lebih kecil dari standar deviasi yang dapat diartikan bahwa data variabel tersebut tidak berkelompok atau bervariasi.

Tabel 5. Hasil Pengujian Overall Model Fit

\begin{tabular}{cc}
\hline Block Number & $\mathbf{- 2} \log$ likehood \\
\hline 0 & 76,228 \\
1 & 60,886 \\
\hline Sumber: Output SPSS 20 &
\end{tabular}

Penurunan nilai antara 2LogL pada langkah awal dengan 2LogL pada langkah berikutnya menunjukkan model regresi yang semakin baik. Sehingga model regresi logistik ini layak digunakan untuk analisis selanjutnya. Nilai -2 LogL pada regresi logistik mirip dengan pengertian 'Sum of Square Error" pada model regresi. Sehingga penurunan nilai -2 LogL menunjukkan model yang semakin baik.

Tabel 6. Koefisien Determinasi

\begin{tabular}{cccc}
\multicolumn{4}{c}{ Model Summary } \\
\hline Step & $\begin{array}{c}-2 \text { Log } \\
\text { likelihood }\end{array}$ & $\begin{array}{c}\text { Cox \& Snell R } \\
\text { Square }\end{array}$ & $\begin{array}{c}\text { Nagelkerke R } \\
\text { Square }\end{array}$ \\
\hline 1 & $60,886 a$ &, 243 &, 325 \\
\hline Sumber: Output SPSS 20 & &
\end{tabular}

Hasil pengujian koefisien determinasi Tabel 6 ditunjukkan dengan nilai Nagelkerke $R$ Square sebesar 0,325 . Nilai Nagelkerke $R$ Square yang sebesar 0,325 atau $32,5 \%$ menunjukkan bahwa variabel independen yang berupa profitabilitas, ukuran perusahaan, dan nilai perusahaan mempengaruhi variabel dependen yaitu praktik perataan laba sebesar 32,5\% sementara sisanya sebesar $67,5 \%$ dijelaskan oleh variabel lain diluar penelitian.

Tabel 7. Omnibus Tests of Model Coefficients

\begin{tabular}{lllll}
\hline & & Chi-square & Df & Sig. \\
\hline Step 1 & Step & 15,342 & 3 &, 002 \\
& Block & 15,342 & 3 &, 002 \\
& Model & 15,342 & 3 &, 002 \\
\hline
\end{tabular}

Sumber: Output SPSS 20

Dari hasil Tabel 7 menunjukkan bahwa nilai Chi-Square yang diperoleh adalah sebesar 15,342 dengan degree of freedom $=3$. Tingkat signifikansi yang dihasilkan adalah 0,002 , berarti secara simultan profitabilitas, ukuran perusahaan, dan nilai perusahaan memiliki pengaruh terhadap perataan laba.

\section{PEMBAHASAN}

Berdasarkan Tabel 4, nilai ROA tertinggi sebesar $41,50 \%$ dimiliki oleh PT. Unilever Indonesia Tbk (UNVR) yang menunjukkan kemampuan perusahaan dalam menghasilkan laba atas aktiva yang digunakan adalah sebesar $41,50 \%$. Nilai ROA terendah dimiliki oleh PT. Lippo Karawaci Tbk (LPKR) yaitu sebesar 2,48\%. Artinya kemampuan perusahaan dalam menghasilkan laba atas aktiva yang digunakan adalah sebesar 2,48\%, hal tersebut disebabkan oleh penurunan penjualan yang cukup signifikan sehingga laba tahun berjalan juga ikut menurun secara signifikan.

Nilai logaritma natural ukuran perusahaan terendah yaitu sebesar 7,23 dimiliki oleh PT. Alam Sutera Realty Tbk (ASRI) pada tahun 2011 dan nilai logaritma natural ukuran perusahaan tertinggi yaitu sebesar 12,21 dimiliki oleh PT. Astra International Tbk (ASII) pada tahun 2014. Hasil tersebut menunjukkan bahwa PT. Astra International Tbk (ASII) termasuk ke dalam kategori perusahaan besar dan PT. Alam Sutera Realty Tbk (ASRI) termasuk ke dalam kategori perusahaan kecil yang terdaftar di Jakarta Islamic Index periode 20112015.

Nilai price to book value variabel nilai perusahaan terendah yaitu sebesar 0,88 dimiliki oleh PT. Lippo Karawaci Tbk (LPKR) dengan nilai harga saham sebesar Rp720 per lembar saham, total ekuitas sebesar Rp18.917 (dalam miliaran rupiah), saham beredar sebesar Rp23.078 (dalam miliaran rupiah) dan nilai book value sebesar 0,82 pada tahun 2015. Sementara itu nilai price to book value variabel nilai perusahaan tertinggi yaitu sebesar 82,13 dimiliki oleh PT. Unilever Indonesia Tbk (UNVR) dengan nilai harga saham sebesar Rp39.625 per lembar saham, total ekuitas sebesar Rp4.827 (dalam miliaran rupiah), saham beredar sebesar Rp7.630 (dalam miliaran rupiah) dan nilai book value sebesar 632,63 pada tahun 2011.

Koefisien regresi $\beta 1-0,149$ dengan nilai signifikansi 0,011 menunjukkan bahwa profitabilitas memiliki pengaruh signifikan dengan arah negatif terhadap perataan laba. Karena analisis regresi logistik tidak bisa diinterpretasikan langsung dengan hanya melihat nilai koefisien regresi, maka dari itu dilihat dari hasil eksponen B bahwa nilai yang dihasilkan adalah 0,861 , nilai tersebut lebih kecil dari 1. Hal tersebut menunjukkan bahwa semakin tinggi nilai variabel profitabilitas maka perusahaan cenderung tidak melakukan perataan laba.

Koefisien regresi $\beta 2-0,552$ dengan nilai signifikansi 0,044 yang menunjukkan bahwa ukuran perusahaan memiliki pengaruh secara signifikan dengan arah negatif terhadap perataan laba. Karena analisis regresi logistik tidak bisa diinterpretasikan langsung dengan hanya melihat nilai koefisien regresi, maka dari itu dilihat dari hasil eksponen B bahwa nilai yang dihasilkan adalah 0,576 , nilai tersebut lebih kecil dari 1 . Hal tersebut menunjukkan bahwa semakin tinggi nilai variabel ukuran perusahaan maka perusahaan cenderung tidak melakukan perataan laba.

Koefisien regresi $\beta 30,052$ dengan nilai signifikansi sebesar 0,049 yang menunjukkan bahwa nilai perusahaan memiliki pengaruh secara signifikan dengan arah positif 
Tabel 9. Variables in the Equation

\begin{tabular}{lcccccccc}
\hline & B & S.E. & Wald & df & Sig. & Exp(B) & \multicolumn{2}{c}{ 95\% C.I.for EXP(B) } \\
\cline { 7 - 10 } & & & & & & & Lower & Upper \\
\hline ROA &,- 149 &, 059 & 6,467 & 1 &, 011 &, 861 &, 768 &, 966 \\
UP &,- 552 &, 273 & 4,075 & 1 &, 044 &, 576 &, 337 &, 984 \\
PBV &, 052 &, 026 & 3,874 & 1 &, 049 & 1,053 & 1,000 & 1,108 \\
Constant & 7,404 & 2,913 & 6,460 & 1 &, 011 & 1643,224 & & \\
\hline
\end{tabular}

Output: SPSS 20

terhadap perataan laba. Karena analisis regresi logistik tidak bisa diinterpretasikan langsung dengan hanya melihat nilai koefisien regresi, maka dari itu dilihat dari hasil eksponen $\mathrm{B}$ bahwa nilai yang dihasilkan adalah 1,053 , nilai tersebut lebih besar dari 1 . Hal tersebut menunjukkan bahwa semakin tinggi nilai variabel nilai perusahaan maka perusahaan akan cenderung melakukan perataan laba.

Dalam penelitian ini profitabilitas diukur dengan menggunakan return on aset (ROA). Tabel 9 menunjukkan bahwa koefisien regresi profitabilitas sebesar -0,149 dengan nilai signifikansi 0,011 lebih kecil dari tingkat signifikansi 5\%. Hasil tersebut signifikan namun tidak mendukung hipotesis yang dikemukakan karena arah yang dihasilkan negatif.

Dalam penelitian ini ukuran perusahaan diproksikan dengan menggunakan logaritma natural total penjualan. Tabel 9 menunjukkan bahwa koefisien regresi ukuran perusahaan sebesar -0,552 dengan tingkat signifikansi 0,044 lebih kecil dari tingkat signifikansi 5\%. Hasil tersebut signifikan namun tidak mendukung hipotesis yang dikemukakan karena arah yang dihasilkan negatif.

Dalam penelitian ini nilai perusahaan diukur dengan menggunakan price to book value. Tabel 9 menunjukkan bahwa koefisien regresi PBV sebesar 0,052 dengan nilai signifikansi 0,049 lebih kecil dari tingkat signifikansi 5\%. Hasil tersebut signifikan namun dan mendukung hipotesis yang dikemukakan karena arah yang dihasilkan positif.

\section{KESIMPULAN}

Berdasarkan uji statistik deskriptif mengenai profitabilitas, ukuran perusahaan, dan nilai perusahaan terhadap praktik perataan laba pada perusahaan yang terdaftar dalam Jakarta Islamic Index tahun 20112015 maka diperoleh hasil sebagai berikut: (a) Dari 55 jumlah sampel perusahaan yang terdaftar dalam Jakarta Islamic Index sebanyak 28 perusahaan atau 50,91\% unit sampel melakukan perataan laba sedangkan sisanya sebanyak 27 perusahaan atau sebesar 49,09\% unit sampel tidak melakukan perataan laba, (b) Profitabilitas pada perusahaan yang terdaftar di Jakarta Islamic Index selama tahun 2011-2015 memiliki nilai ratarata profitabilitas sebesar $15,36633 \%$ dengan nilai standar deviasi sebesar 9,49030\%. Dari total 55 sampel penelitian terdapat 23 sampel memiliki nilai diatas rata- rata dengan 11 sampel tergolong smoother dan sisanya sebanyak 12 sampel tergolong non-smoother. Sementara itu sebanyak 32 sampel dibawah rata-rata dimana 17 sampel tergolong smoother dan sisanya sebanyak 15 sampel tergolong non-smoother, (c) Ukuran perusahaan pada perusahaan yang terdaftar di Jakarta Islamic Index tahun 2011-2015 memiliki nilai rata-rata logaritma natural sebesar 9,87569 dengan nilai standar deviasi sebesar 1,23047. Dari total 55 sampel penelitian terdapat 25 sampel yang memiliki nilai rata-rata diatas rata-rata dengan 10 sampel tergolong smoother dan sisanya 15 sampel tergolong non-smoother. Sementara itu sebanyak 30 sampel dibawah rata-rata dengan 18 sampel tergolong smoother dan sisanya sebanyak 12 sampel tergolong non-smoother, (d) Nilai perusahaan pada perusahaan yang terdaftar di Jakarta Islamic Index tahun 2011-2015 memiliki nilai rata-rata PBV sebesar 9,06963 dengan nilai standar deviasi sebesar 20,22630. Dari total 55 sampel penelitian terdapat 6 sampel yang memiliki nilai rata-rata diatas rata-rata dengan 1 sampel tergolong smoother dan sisanya 5 sampel tergolong nonsmoother. Sementara itu sebanyak 49 sampel dibawah rata-rata dengan 27 sampel tergolong smoother dan sisanya sebanyak 22 sampel tergolong non-smoother.

Berdasarkan hasil pengujian regresi logistik menggunakan Omnimbus Test of Model Coefficients diketahui bahwa secara simultan profitabilitas, ukuran perusahaan, dan nilai perusahaan memiliki pengaruh terhadap perataan laba pada perusahaan yang terdaftar di Jakarta Islamic Index tahun 2011-2015.

Berdasarkan hasil pengujian dan ukuran perusahaan secara parsial diketahui bahwa profitabilitas berpengaruh negatif signifikan, sedangkan nilai perusahaan berpengaruh positif signifikan terhadap praktik perataan laba pada perusahaan yang terdaftar di Jakarta Islamic Index tahun 2011-2015.

\section{DAFTAR PUSATAKA}

Belkaoui, Ahmed Riahi. 2007. Accounting Theory (Buku 2). Edisi Kelima. Jakarta: Salemba Empat. Dewi, Made Yustiari \& Sujana, I Ketut. 2014. Pengaruh Ukuran Perusahaan dan Profitabilitas Pada Praktik Perataan Laba Dengan Jenis Industri Sebagai Variabel Pemoderasi di Bursa Efek Indonesia. E-Journal Akuntansi Universitas Udayana. (ISSN: $2302-8556$ ). 
Hery. 2015. Analisis Laporan Keuangan. Yogyakarta: CAPS.

Ikatan Akuntan Indonesia.2015. Standar Akuntansi Keuangan Edisi 2015. Penerbit: Salemba Empat. Jakarta.

Marpaung, c.o., \& Latrini, Y 2014. Pengaruh Dewan Komisaris Independen, Komite Audit, Kualitas Audit, Dan Kepemilikan Manajerial Pada Perataan Laba. E-Jurnal Akuntansi Universitas Udayana 7.2, 279-289.

Mulford, Charless W. dan Comiskey, Eugene E. 2010. Deteksi Kecurangan Akuntansi. Jakarta: PPM.

Peranasari, I. A., \& Dharmadiaksa, I. B. 2014. Pelaku Income Smoothing, Dan Faktor-Faktor Yang Memengaruhinya. E-Jurnal Akuntansi Universitas Udayana 8.1, 140-153.

Putri, Noviantara Dwi \& Yuyetta, Etna Nur Afri. 2013. Pengaruh Struktur Kepemilikan dan Kualitas Audit Terhadap Manajemen Laba. E-Jurnal Akuntansi Universitas Diponegoro Vol 2. ISSN: 2337-3806
Subramanyam, K. R., \& Wild, J.J.2013. Financial Statement Analysis. Analisis Laporan Keuangan. (D. Yanti, Trans.) Jakarta: Salemba Empat.

Warnanti, S.S.A., 2015. Ukuran Perusahaan, Winner/ Loser Stock, Debt to Equity Ratio, Dividend Payout Ratio Pengaruh Terhadap Perataan Laba. Paradigma, 13(01), pp.45-62.

Widana, N. and Ari, I.N., 2013. Perataan laba serta faktor-faktor yang mempengaruhinya di Bursa Efek Indonesia. E-Jurnal Akuntansi, 3(2), pp.297-317.

Wulandari, S., Arfan, M., \& Shabri, M. 2013. Pengaruh Profitabilitas, Operating Profit Margin (OPM), Dan Financial Leverage Terhadap Perataan Laba (Income Smoothing) Pada Perusahaan Blue Chips Di Indonesia (Studi Empiris Pada Perusahaan LQ45 Yang Terdaftar Di Bursa Efek Indonesi Tahun 20072011). Jurnal Akuntansi PascaSarjana Universitas Syiah Kuala, 2, 44-55.

Yayasan Pendidikan Internal Audit. Fraud Auditing. 2008

Tabel 8. Tingkat Profitabilitas, Nilai Perusahaan dan Ukuran Perusahaan yang Terdaftar di Jakarta Islamic Index tahun 2011-2015

(dalam miliaran rupiah)

\begin{tabular}{|c|c|c|c|c|c|}
\hline \multirow{2}{*}{ NO. } & \multirow{2}{*}{$\begin{array}{c}\text { NAMA } \\
\text { PERUSAHAAN }\end{array}$} & \multirow{2}{*}{ TAHUN } & PROFITABILITAS & UKURAN PERUSAHAAN & NILAI PERUSAHAAN \\
\hline & & & ROA & Ln TOTAL PENJUALAN & PBV \\
\hline \multirow[t]{5}{*}{1.} & AALI & 2011 & 24,4806 & 9,28480 & 3,10290 \\
\hline & & 2012 & 20,29149 & 9,35565 & 2,79178 \\
\hline & & 2013 & 12,71804 & 9,44739 & 2,54601 \\
\hline & & 2014 & 14,12329 & 9,69929 & 2,20875 \\
\hline & & 2015 & 3,230755 & 9,47723 & 2,23481 \\
\hline \multirow[t]{5}{*}{2.} & ASII & 2011 & 13,65807 & 11,99883 & 4,29727 \\
\hline & & 2012 & 12,47682 & 12,14448 & 3,62857 \\
\hline & & 2013 & 10,41945 & 12,17499 & 3,06905 \\
\hline & & 2014 & 9,373848 & 12,21454 & 2,70849 \\
\hline & & 2015 & 6,361358 & 12,12376 & 2,57558 \\
\hline \multirow[t]{5}{*}{3.} & ASRI & 2011 & 10,03829 & 7,23056 & 2,37148 \\
\hline & & 2012 & 11,10908 & 7,80221 & 1,39673 \\
\hline & & 2013 & 6,16163 & 8,21175 & 1,36349 \\
\hline & & 2014 & 6,948712 & 8,20001 & 1,14113 \\
\hline & & 2015 & 3,655799 & 7,93164 & 1,10120 \\
\hline \multirow[t]{5}{*}{4.} & INTP & 2011 & 19,84464 & 9,53878 & 3,45664 \\
\hline & & 2012 & 20,93166 & 9,75788 & 2,80070 \\
\hline & & 2013 & 18,83715 & 9,83580 & 2,36691 \\
\hline & & 2014 & 18,25861 & 9,90329 & 2,19434 \\
\hline & & 2015 & 15,76453 & 9,78684 & 2,27884 \\
\hline \multirow[t]{5}{*}{5.} & KLBF & 2011 & 18,40706 & 9,29762 & 2,32235 \\
\hline & & 2012 & 18,84689 & 9,52047 & 10,26346 \\
\hline & & 2013 & 17,41052 & 9,68047 & 8,21691 \\
\hline & & 2014 & 17,07042 & 9,76244 & 7,11457 \\
\hline & & 2015 & 15,02629 & 9,79183 & 6,38542 \\
\hline
\end{tabular}




\begin{tabular}{|c|c|c|c|c|c|}
\hline \multirow[t]{5}{*}{6.} & LSIP & 2011 & 25,05889 & 8,45233 & 1,96896 \\
\hline & & 2012 & 14,77754 & 8,34569 & 1,83069 \\
\hline & & 2013 & 9,630094 & 8,32700 & 1,79833 \\
\hline & & 2014 & 10,59503 & 8,46105 & 1,64169 \\
\hline & & 2015 & 7,040344 & 8,34046 & 1,56674 \\
\hline \multirow[t]{5}{*}{7.} & LPKR & 2011 & 5,3946 & 8,34046 & 1,76599 \\
\hline & & 2012 & 6,341228 & 8,72583 & 1,44866 \\
\hline & & 2013 & 5,086262 & 8,80478 & 1,17280 \\
\hline & & 2014 & 8,302217 & 9,36349 & 0,94297 \\
\hline & & 2015 & 2,477799 & 9,09493 & 0,87837 \\
\hline \multirow[t]{5}{*}{8.} & SMGR & 2011 & 20,11494 & 9,70376 & 3,50075 \\
\hline & & 2012 & 18,53719 & 9,88318 & 2,81660 \\
\hline & & 2013 & 17,38763 & 10,10647 & 2,35224 \\
\hline & & 2014 & 16,48025 & 10,20311 & 2,04613 \\
\hline & & 2015 & 11,86014 & 10,20166 & 1,86449 \\
\hline \multirow[t]{5}{*}{9.} & TLKM & 2011 & 15,01155 & 11,17399 & 1,31246 \\
\hline & & 2012 & 16,48753 & 11,25342 & 1,19495 \\
\hline & & 2013 & 15,85763 & 11,32620 & 5,16863 \\
\hline & & 2014 & 15,22126 & 11,40418 & 4,64646 \\
\hline & & 2015 & 14,03176 & 11,53733 & 4,28326 \\
\hline \multirow[t]{5}{*}{10.} & UNTR & 2011 & 12,70457 & 10,91605 & 2,90220 \\
\hline & & 2012 & 11,43715 & 10,93229 & 2,47127 \\
\hline & & 2013 & 8,366166 & 10,83982 & 2,23911 \\
\hline & & 2014 & 8,027599 & 10,88072 & 2,06916 \\
\hline & & 2015 & 4,563956 & 10,80663 & 2,03368 \\
\hline \multirow[t]{5}{*}{11.} & UNVR & 2011 & 39,72524 & 10,06344 & 82,13495 \\
\hline & & 2012 & 40,37547 & 10,21475 & 76,19424 \\
\hline & & 2013 & 40,10339 & 10,33378 & 74,32123 \\
\hline & & 2014 & 41,5027 & 10,44906 & 63,69049 \\
\hline & & 2015 & 37,2028 & 10,50463 & 62,63492 \\
\hline
\end{tabular}

